Kontekstuliasasi Nusyuz... Oleh: Mughniatul Ilma

\title{
KONTEKSTUALISASI KONSEP NUSYUZ DI INDONESIA
}

\author{
Oleh: \\ Mughniatul Ilma \\ mughniatulilma@gmail.com \\ Institut Agama Islam Negeri (IAIN) Ponorogo
}

\begin{abstract}
Dalam Q.S. an-Nisa' ayat 34 dijelaskan mengenai tiga tahapan yang dapat dilakukan bagi isteri yang melakukan nusyūz. Hal yang dianggap paling krusial dalam hal ini adalah adanya term pemukulan dalam konsep nusyūz tersebut yang sering kali dianggap sebagai bentuk legitimasi terhadap adanya kekerasan dalam rumah tangga terutama terhadap perempuan. Oleh karena itu, perlu adanya kontekstualisasi terhadap ayat nusyūz tersebut terlepas dari keadaan sosio kultural masyarakat yang melingkupi turunnya ayat maupun yang melingkupi meja perumusan doktrin fikih oleh ulama di zamannya. Tulisan ini mencoba melakukan pemaknaan ulang terhadap konsep nusyūz agar semangat hukum Islam dalam menjawab permasalahan umat selalu sejalan dengan tujuan pensyariatan sesuai dengan ruang dan kebutuhan zaman.
\end{abstract}

Kata Kunci: Konsep Nuzyuz.

\section{Pendahuluan}

Perkawinan merupakan suatu perjanjian yang kokoh ( ميثاقا غليظا). Perkawinan sebagai hubungan suami dan isteri merupakan hubungan dan ikatan yang melebihi ikatan-ikatan yang lain karena perkawinan memiliki beberapa tujuan yang mulia dan sakral yakni untuk menciptakan dan membentuk keluarga yang tenteram, penuh cinta dan kasih sayang yang 
dalam bahasa al-Quran adalah sakinah mawaddah wa rahmah, ${ }^{1}$ sebagaimana dalam ayat berikut ini:

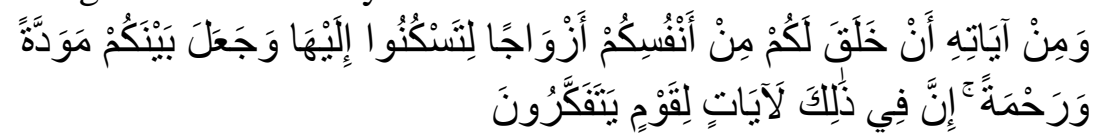

Terjemahnya: "Dan di antara tanda-tanda kekuasaan-Nya ialah

Dia menciptakan untukmu isteri-isteri dari jenismu sendiri, supaya kamu cenderung dan merasa tenteram kepadanya, dan dijadikan-Nya diantaramu rasa kasih dan sayang. Sesungguhnya pada yang demikian itu benar-benar terdapat tanda-tanda bagi kaum yang berfikir." 2

Terwujudnya keluarga yang sakinah, mawaddah dan rahmah akan mendatangkan keharmonisan dan kebahagiaan dalam sebuah perkawinan. Setiap orang umumnya mengharapkan hal tersebut terwujud dalam mahligai rumah tangganya. Namun, realitanya kehidupan rumah tangga tidak selalu berjalan mulus. Adanya cekcok, pertengkaran, perseteruan hingga kekerasan adalah hal yang kerap kali terjadi. Oleh karena itu, pasangan suami istri harus mampu menyikapi segala permasalahan rumah tangga dengan bijaksana melalui jalan musyawarah secara baik-baik, menghindari tindakan saling menyalahkan satu sama lain, membiasakan diri untuk saling mengingatkan dan menghormati pasangannya. Selain itu, hal mutlak yang harus diperhatikan oleh pasangan suami istri yakni pemenuhan hak dan kewajiban satu sama lain. Pengabaian terhadap hak dan kewajiban yang dilakukan oleh istri maupun suami inilah yang sering kali memicu konflik dalam rumah tangga. Dalam term hukum Islam, hal ini biasa disebut dengan nusyüz.

${ }^{1}$ Khoiruddin Nasution, Hukum Perkawinan 1, ed. revisi (Yogyakarta: ACAdeMIA + TAZZAFA, 2005), h. 25.

${ }^{2}$ Ar-Rūm (30) : 21. 
Nusyüz biasa diartikan dengan kedurhakaan, pembangkangan istri terhadap suami ataupun sebaliknya. Istri dapat dianggap nusyūz apabila ia tidak melaksanakan kewajibannya atau tidak memenuhi hak-hak yang semestinya diperoleh oleh suami begitu juga sebaliknya. Adapun penyebab perbuatan nusyūz itu bermacam-macam, antara lain ketidakpuasan terhadap pasangannya, tuntutan berlebih hingga tidak mematuhi perintah atau tidak menuruti permintaan pasangan.

Hukum Islam melalui ayat Q.S. an-Nisa' ayat 34 menegaskan tentang tiga tahapan yang dapat dilakukan untuk mengatasi istri yang nusyüz. Dalam ayat tersebut dinyatakan bahwa suami boleh melakukan tiga hal secara bertahap terhadap istrinya yang melakukan nusyūz yakni, 1) menasehati, 2) memisah ranjang, dan 3) memukul, dimana ketiganya dilakukan secara bertahap apabila point sebelumnya belum mampu mengubah tabiat sang istri. Dari ketiga tahapan tersebut, salah satu point yang sering menjadi perdebatan ialah tahapan terakhir yakni pemukulan. Secara eksplisit, hal ini kerap diartikan sebagai bentuk legitimasi terhadap adanya kekerasan dalam rumah tangga (selanjutnya disebut KDRT). Sejumlah ulama klasik dan kontemporer memberikan interpretasi yang berbeda dengan berbagai macam argumentasi. Sebagian menafsirkan dengan pemukulan yang dibatasi untuk bagian-bagian tertentu, pemukulan dengan kasih sayang, memberi contoh / mendidik, hingga diinterpretasikan dengan persetubuhan bahkan perceraian.

Di sisi lain, Indonesia memiliki UU No. 23 Tahun 2004 tentang Penghapusan Kekerasan Dalam Rumah Tangga sebagai payung hukum bagi korban tindak KDRT serta sebagai dasar hukum tindak pidana bagi pelakunya. Pasal 1 UU tersebut menyatakan bahwa tindakan kekerasan dalam rumah tangga adalah "setiap perbuatan terhadap seseorang terutama 
perempuan, yang berakibat timbulnya kesengsaraan atau penderitaan secara fisik, seksual, psikologis, dan atau menelantarkan rumah tangga, termasuk ancaman untuk perbuatan, pemaksaan, atau perampasan kemerdekaan secara melawan hukum dalam lingkup rumah tangga”. Kekerasan tersebut meliputi kekerasan fisik, kekerasan psikis, kekerasan seksual hingga penelantaran rumah tangga. Dilihat dari jenisjenis kekerasan tersebut, term "pemukulan" dalam konsep $n u s y \bar{u} z$ dapat dikategorikan sebagai kekerasan fisik. Kenyataan inilah yang akhirnya membuat reinterpretasi konsep nusyūz menjadi penting adanya.

Hukum Islam yang bersifat universal memiliki kelenturan dan upaya adaptasi dalam segala kondisi dan situasi. Hal ini berarti hukum Islam harus mampu mangakomodir seluruh kebutuhan hukum masyarakat dalam setiap lintasan waktu. Hukum Islam yang bersifat dinamis selalu seiring dan sejalan dengan perubahan zaman, di manapun tempatnya dan bagaimanapun keadaannya. Mengutip dari pendapat al-Jauziyah:

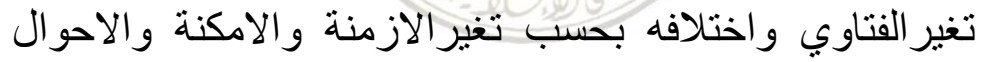

و العو اعد

Dapat disimpulkan bahwa perubahan pemikiran hukum Islam dan segala bentuk perbedaan pendapatnya sejalan dengan perubahan waktu, tempat, keadaan dan kebutuhan. Selain itu, alJauziyah menyatakan bahwa kesalahan besar dalam syariat ialah tidak mempertimbangkan perubahan. ${ }^{3}$

Stagnasi hukum Islam yang terkungkung dalam pemikiran klasik dengan sosio kultural yang telah terlampaui memerlukan adanya pembaruan hukum Islam. Ayat nusyūz yang dituding melegalkan adanya pemukulan terhadap isteri sebagai hasil budaya patriarki meniscayakan adanya pemaknaan ulang

${ }^{3}$ Ibnu Qayyim al-Jauziyah, I'lam al-Muwaqqiin an Rab al-Alamin (Beirut: Dar al-Fikr, t. th.), III: 14. 
Kontekstuliasasi Nusyuz... Oleh: Mughniatul Ilma

dikaitkan dengan pranata sosial dan hukum negara yang bersangkutan.

Berangkat dari hal tersebut, penulis bermaksud menyumbangkan pemikiran mengenai kontekstualisasi konsep $n u s y \bar{u} z$ agar tidak melahirkan pemahaman yang salah di tengah maraknya kasus kekerasan dalam rumah tangga (KDRT) sehingga konsep nusyūz sebagai bagian dari hukum Islam tidak dianggap menyeleweng dari cita hukum positif di Indonesia khususnya UU Penghapusan Kekerasan Dalam Rumah Tangga.

\section{Pembahasan}

\section{Nusyūz: Antara Fikih Klasik dan Kontemporer}

Secara bahasa, nusyūz adalah bentuk isim mashdar atau infinitive dari kata, نشز - ينشز yang mempunyai arti terangkat tinggi ke atas. ${ }^{4}$ Sedangkan menurut al-Qurthubi, makna فاشز adalah ما ارتفع من الأَرض (sesuatu yang terangkat ke atas dari bumi). ${ }^{5}$ Adapun Ahmad Warson Munawwir dalam kamusnya memberi arti nusyūz dengan tempat yang tinggi. Dan jika konteksnya dikaitkan dengan hubungan suami-isteri maka ia mengartikan sebagai kedurhakaan, penentangan istri terhadap suami.

Adapun secara istilah, nusyūz ialah meninggalkan kewajiban suami istri atau sikap acuh tak acuh yang ditunjukkan oleh suami atau istri. Namun, umumnya nusyūz diartikan sebagai durhaka atau kedurhakaan. ${ }^{6}$ Ulama Hanafiyyah berpendapat, nusy $\bar{u} z$ ialah ketidaksenangan yang terjadi di antara

${ }^{4}$ Muhammad Ali ash-Shabuni, Rawai'ul Bayan: Tafsir Ayat-Ayat Hukum, Pentj. Moh. Zuhri dan M. Qodirun Nur (Semarang: Asy-Syifa, 1993), II: 275.

${ }^{5}$ Syaikh Imam Al-Qurthubi, Tafsir Al-Qurthubi, terj. Ahmad Rijali Kadir (Jakarta: Pustaka Azzam, 2008) h. 396.

${ }^{6}$ Dudung Abdul Rohman, Mengembangkan Etika Berumah Tangga Menjaga Moralitas Bangsa Menurut Pandangan Al-Qur'an (Bandung: Nuansa Aulia, 2006), h. 93.

Volume 30 Nomor 1 Januari-Juni 2019 
suami dan isteri. Sedangkan ulama Syafi'iyyah mengartikan $n u s y \bar{u} z$ sebagai perselisihan yang terjadi di antara suami isteri. Pendapat serupa juga dinyatakan oleh ulama Malikiyyah dengan arti permusuhan atau perseteruan antara suami isteri. Sedangkan ulama Hanbaliyyah memberikan definisi sebagai bentuk ketidaksenangan dari pihak isteri atau pun suami disertai dengan hubungan yang tidak harmonis. ${ }^{7}$

Selain imam-imam madzhab di atas, beberapa ulama juga ikut mendefinisikan nusyūz dalam karya mereka. Wahbah alZuhaili dalam kitabnya al-Fiqh al-Islam wa Adillatuh mendefinisikan nusyūz sebagai ketidakpatuhan atau kebencian suami kepada isteri terhadap apa yang seharusnya dipatuhi begitupun sebaliknya. Sedangkan Ibnu Manzur dalam kitab Lisan al-'Arab mengartikan nusyūz sebagai rasa kebencian suami terhadap isteri atau sebaliknya. Sayyid Sabiq dalam kitab Fiqh al-Sunnah memberi definisi sebagai kedurhakaan dan ketidaktaatan isteri kepada suami termasuk keluar rumah tanpa izin suaminya dan menolak permintaan suami untuk diajak ke tempat tidur. ${ }^{9}$ Definisi lain juga diberikan oleh Hamka dalam Tafsir al-Azhar dengan arti tidak takut dan tidak taat baik kepada Allah maupun suami. ${ }^{10}$ Sementara M. Quraish Shihab dalam Tafsir al-Mishbāh menafsirkan nusyūz dengan arti keangkuhan dan pembangkangan. ${ }^{11}$

${ }^{7}$ Shaleh bin Ghanim as-Sadlani, Nusyūz , Konflik Suami Isteri dan Penyelesaiannya, Pentj. Muhammad Abdul Ghafar (Jakarta: Pustaka alKautsar, 1993), h. 26

8 Abdul Aziz Dahlan, Ensiklopedi Hukum Islam, Vol. 4, Cet. I (Jakarta: Ichtiar Baru Van Hoeve, 1996), h. 1353-1354.

${ }^{9}$ Sayyid Sabiq, Fiqh al-Sunnah (Madinah: al-Fath Li I'lami al-'Araby, 1990), II: 314.

${ }^{10}$ Hamka, Tafsir al-Azhar, Juz V (Jakarta: Pustaka Panjimas, 1983), h. 60.

11 M. Quraish Shihab, Tafsir Al-Mishbah: Pesan, Kesan dan Keserasian Al-Qur'an, Vol. 2 (Jakarta: Lentera Hati, 2006), h. 430. 
Dari beberapa pendapat mengenai definisi nusyūz di atas dapat diambil kesimpulan bahwa nusyz̄z adalah kedurhakaan, ketidaksenangan, permusuhan, perlawanan, kebencian dan ketidakpatuhan istri terhadap suami atau pun sebaliknya.

Adapun ayat al-Quran yang menjadi dasar hukum nusyūz yaitu:

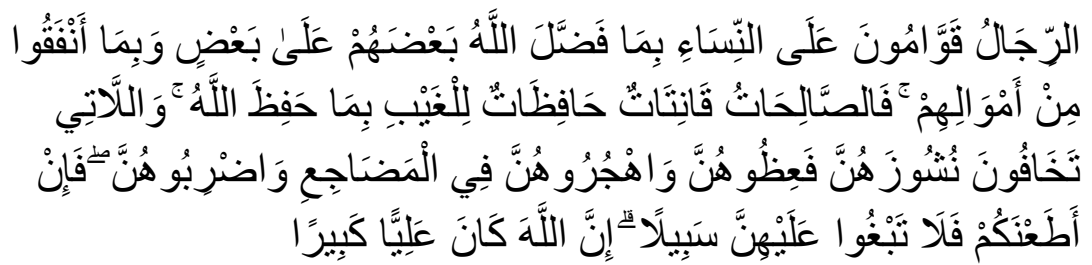

Artinya: "Kaum laki-laki itu adalah pemimpin bagi kaum wanita, oleh karena Allah telah melebihkan sebahagian mereka (laki-laki) atas sebahagian yang lain (wanita), dan karena mereka (laki-laki) telah menafkahkan sebagian dari harta mereka. Sebab itu maka wanita yang saleh, ialah yang taat kepada Alla $\mathrm{h}$ lagi memelihara diri ketika suaminya tidak ada, oleh karena Allah telah memelihara (mereka). Wanitawanita yang kamu khawatirkan nusyuznya, maka nasehatilah mereka dan pisahkanlah mereka di tempat tidur mereka, dan pukullah mereka. Kemudian jika mereka mentaatimu, maka janganlah kamu mencaricari jalan untuk menyusahkannya. Sesungguhnya Allah Maha Tinggi lagi Maha Besar". ${ }^{12}$

Adapun asbab al-nuzul Q.S. an-Nisa' (4) ayat 34 tersebut ialah peristiwa yang dialami Habibah binti Zaid bin Abi Zuhair dengan suaminya Sa'ad bin Rabi' bin 'Amr. Sa'ad merupakan salah seorang pemuka golongan Anshar. Suatu ketika Habibah ditampar oleh suaminya karena dianggap durhaka. Kemudian Habibah mengajak ayahnya mengadu kepada Rasulullah SAW. Rasulullah pun bersabda:

${ }^{12}$ Q.S. an-Nisa' (4) : 34.

Volume 30 Nomor 1 Januari-Juni 2019 


\section{لتقتصن من زوجها}

Artinya: "Hendaklah Dia mengqishas suaminya". Kemudian Habibah bersama ayahnya pergi untuk mengqishas Sa'ad. Tetapi kemudian Rasulullah memanggil mereka kembali dan memberitahukan kepada keduanya bahwa Jibril telah membawa wahyu Q.S. an-Nisa': 34. Lalu Rasulullah bersabda:

$$
\text { أردنا أمرا, و الله أر اد أمراً, و الذي ار اد الله خير }
$$

Artinya: "Kita memiliki kehendak tentang suatu perkara, Allah pun memiliki kehendak tentang suatu perkara. Sedangkan kehendak Allah adalah lebih baik". Akhirnya perintah qishas tersebut dicabut oleh Rasulullah. ${ }^{13}$

Imam madzhab berpendapat mengenai perbuatan isteri yang dapat dikategorikan nusyuzz. Adapun pendapat Ulama Hanafiyyah yakni isteri keluar dari rumah suaminya tanpa izin dan menutup diri dari suaminya. Sedangkan ulama Syafi'iyyah mengkategorikan dengan kedurhakaan sang isteri kepada suaminya dan pelanggaran-pelanggaran terhadap perintahperintah yang diwajibkan Allah kepadanya. Sementara ulama Malikiyyah menyebutkan diantaranya pelanggaran yang dilakukan isteri terhadap ketentuan-ketentuan yang wajib ditaati, menolak suami untuk menggaulinya, menutup pintu atau tidak mengizinkan suami masuk ke tempat tidurnya, keluar rumah suami tanpa izin padahal dia tahu jika suami tidak akan mengizinkannya, meninggalkan kewajiban terhadap Allah seperti tidak mau mandi jinabat, shalat, dan puasa Ramadhan. Sedangkan kategori nusyüz menurut ulama Hanbaliyyah yaitu pelanggaran isteri terhadap hak-hak yang wajib diberikan kepada suami selama menikah. ${ }^{14}$ 279.

${ }^{13}$ Muhammad Ali ash-Shabuni, Rawai'ul Bayan: Tafsir Ayat, II: 278-

${ }^{14}$ Shaleh bin Ghanim as-Sadlani, Nusyūz , Konflik Suami Isteri, h. 2627. 
Sebagian ulama berpendapat, untuk mendeteksi perbuatan $n u s y \bar{u} z$ yang dilakukan oleh istri dapat dilakukan dengan melihat kebiasaannya sehari-hari (qarinah) atau tindakannya dalam melayani suami terlihat berbeda dari biasanya. Rasyid Ridha dalam Tafsir al-Manar menjelaskan bahwa penting untuk mengetahui sebab timbulnya nusyūz, karena nusyūz itu bukanlah tabiat asli perempuan, melainkan sifat yang timbul kemudian. ${ }^{15}$

Ayat و واللاتي تخافون نشوز هن menjelaskan tentang tiga langkah yang ditempuh suami tatkala istrinya nusyüz. Ketiga langkah tersebut adalah menasehati, pisah ranjang dan memukul. Dalam Tafsir al-Mishbāh, M. Quraish Shihab menyatakan bahwa huruf wawu yang digunakan sebagai penghubung ketiga langkah tersebut mengindikasikan langkah yang sebaiknya ditempuh secara berurutan. ${ }^{16}$ Langkah-langkah tersebut antara lain:

\section{Menasehati (فغظو هن )}

Jumhur ulama sepakat bahwa menasehati merupakan cara yang paling penting sehingga cara ini ditempatkan pada urutan pertama dalam penanganan masalah nusyzuz. Dalam hal ini suami harus mengedepankan upaya edukatif dan persuasif terhadap isteri. Hal ini dapat dilakukan dengan dialog terbuka secara halus untuk membicarakan konflik yang sedang mengganggu rumah tangga sehingga suami dapat melakukan perbaikan secara perlahan terhadap nusyüz yang dilakukan oleh isteri. Dalam menasehati, suami diharapkan mengingatkan kembali tentang arti perkawinan yang harus dijaga bersama dan menyampaikan dampak buruk yang akan ditimpa apabila kesalahannya terus dilakukan.. ${ }^{17}$

${ }^{15}$ Abdul Halim Hasan, Tafsir al-Ahkam, (Jakarta: Kencana, 2006), h. 264.

${ }^{16}$ M. Quraish Shihab, Tafsir Al-Mishbah, h. 430.

${ }^{17}$ Shaleh bin Ghanim as-Sadlani, Nusyūz , Konflik Suami Isteri, h. 46. 
Makna lafadz Fa'idzūhunna menurut M. Quraish Shihab yakni suami memiliki kewajiban untuk memperhatikan hak dan kepentingan pasangannya, dan isteri juga memiliki kewajiban mendengarkan dan mengikuti suaminya. Hamka menambahkan, dalam menasehati isteri, suami diharapkan mampu memilah kata-kata dan menentukan sikap yang layak. ${ }^{18}$

Salah satu ulama Syafi'iyyah, Imam al-Ghazali berpendapat bahwa mau'idzah (nasehat) adalah langkah persuasif yang harus selalu diutamakan dalam menyelesaikan setiap konflik dalam rumah tangga. Akan tetapi, jika konflik tersebut cukup krusial dan tidak dapat diselesaikan oleh kedua belah pihak baik suami maupun istri, maka mereka dapat meminta bantuan pihak ketiga (hakam/mediator) sebagai penengah untuk menyelesaikan masalah yang terjadi. ${ }^{19} \mathrm{Hal}$ ini berdasarkan firman Allah Q.S. an-Nisa' (4) ayat 35:
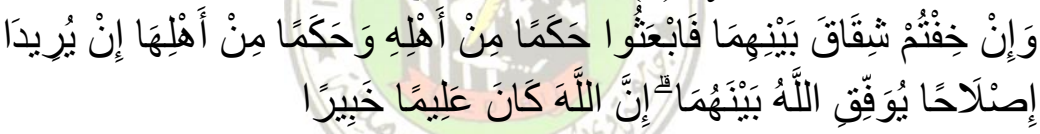

Artinya: "Dan jika kamu khawatirkan ada persengketaan antara keduanya, Maka kirimlah seorang hakam dari keluarga laki-laki dan seorang hakam dari keluarga perempuan. jika kedua orang hakam itu bermaksud Mengadakan perbaikan, niscaya Allah memberi taufik kepada suami-isteri itu. Sesungguhnya Allah Maha mengetahui lagi Maha Mengenal."

Hal senada juga dipaparkan oleh Amina Wadud. Menurutnya, menasehati merupakan solusi verbal antara suami isteri atau dengan bantuan penengah. Tindakan ini merupakan solusi terbaik yang lebih disukai al-Quran, karena keduanya harus berdiskusi mengenai persoalan nusyüz itu. Langkah ini

${ }^{18}$ Hamka, Tafsir al-Azhar..., h. 60.

19 Al-Ghazali, Menyingkap Hakikat Perkawinan ; Adab, Tata Cara dan Hikmahnya, cet. ke-10, terj. Muhammad Al-Baqir (Bandung : Karisma, 1999), h. 15. 
juga sejalan dengan prinsip umum al-Quran untuk melakukan musyawarah atau syura, yang merupakan cara terbaik untuk menyelesaikan masalah dua pihak yang bertikai. ${ }^{20}$

Penempatan nasehat sebagai langkah pertama ini meniscayakan penyelesaian masalah dengan cara yang paling baik dan halus, sehingga suasana menjadi kondusif yang akhirnya dapat memudahkan terciptanya relasi yang kembali harmonis. Oleh karena itu, dalam kehidupan berumah tangga perlu adanya komunikasi yang baik antara suami dan istri dalam setiap masalah yakni melalui jalan musyawarah dalam setiap pengambilan keputusan dan sikap keterbukaan terhadap pendapat satu sama lain. ${ }^{21}$

2. Pisah ranjang (واهجروهن)

Secara etimologis hajr berarti meninggalkan, memisahkan dan tidak berhubungan dengan obyek yang dimaksud. Kata ini tidak digunakan untuk sekedar meninggalkan sesuatu, tetapi ia juga mengandung dua hal. Pertama, bahwa sesuatu yang ditinggalkan itu buruk atau tidak baik, dan yang kedua ia ditinggalkan untuk menuju ke tempat atau keadaan yang lebih baik. $^{22}$ Secara epistemologis atau istilah para fuqaha', hajr adalah seorang suami yang tidak menggauli isterinya, tidak mengajaknya bicara, tidak mengadakan hubungan atau kerja sama apapun dengannya. ${ }^{23}$ Ath-Thabari mengungkapkan, maksud dari kata اهجروهن ini ialah tidak menggauli, mengacuhkan, tidak mengajak berbicara bahkan memalingkan punggung, meskipun tetap berada dalam satu ranjang. ${ }^{24}$

20 Amina Wadud Muhsin, Wanita di dalam al-Qur'an, judul asli: Qur'an and Woman, editor: Ammar Haryono (Bandung: Pustaka, 1994), h. 100-101.

21 Khoiruddin Nasution, Hukum Perkawinan I, ed. revisi, (Yogyakarta: ACAdeMIA dan TAZAFFA, 2005), h. 52.

${ }^{22}$ M. Quraish Shihab, Tafsir Al-Mishbah, h. 430.

${ }^{23}$ Shaleh bin Ghanim as-Sadlani, Nusyūz, Konflik Suami Isteri, h. 25.

${ }^{24}$ Abu Ja'far Muhammad Bin Jarir Ath-Thabari, Tafsir Ath-Thabari, Pentj. Akhmad Affandi (Jakarta: Pustaka Azzam, 2008), VI: 902.

Volume 30 Nomor 1 Januari-Juni 2019 
M. Quraish Shihab menerjemahkan kata فى المضاجع dengan arti "di tempat pembaringan" yang menunjukkan bahwa suami tidak meninggalkan istri di rumah, bahkan tidak juga meninggalkannya di kamar tidur. Hal ini dikarenakan ayat tersebut menggunakan kata فى yang berarti $d i$ tempat tidur bukan s yang berarti meninggalkan dari tempat tidur. Dengan demikian, hendaknya suami tidak meninggalkan tempat dimana biasanya ia tidur. Kejauhan dari pasangan yang sedang dilanda kesalahpahaman justru akan memperlebar jurang perselisihan. Perselisihan hendaknya tidak diketahui oleh orang lain, bahkan anak-anak dan anggota keluarga di rumah sekalipun. Untuk menunjukkan ketidaksenangan suami terhadap istri, sekalipun suami tetap berada di kamar adalah dengan menunjukkan ketidaktertarikan suami terhadap istri seperti tidak adanya cumbu, kata-kata manis ataupun hubungan seks. Ketika itu wanita akan menyadari bahwa daya tariknya tidak lagi dapat menggairahkan suami. Sehingga diharapkan istri dapat menyadari kesalahannya dan keadaan menjadi lebih baik. ${ }^{25}$

Al-Qurthubi mengungkapkan apabila suami berpaling dari istrinya (tidak menggaulinya), maka jika isteri benar-benar mencintai suaminya, hal itu akan membuat dia susah sehingga dia akan kembali untuk berbaikan. Dan jika ia membencinya, maka akan muncul penentangan dari istri, sehingga akan tampak bahwa penentangan datang dari pihak istri. ${ }^{26}$ Pendapat serupa juga dinyatakan oleh Muhammad Abduh, bagi istri yang sangat mencintai suaminya, langkah kedua ini dapat menjadi sanksi yang efektif dikarenakan dengan dikucilkan ia akan merasa sangat menderita. Pisah ranjang tidak selalu berarti meninggalkan tempat tidur dan menjauhi istri karena dikhawatirkan justru akan menambah kebencian istri sehingga bertambah kadar nusyūznya. Hal tersebut dapat dilakukan

${ }^{25}$ M. Quraish Shihab, Tafsir Al-Mishbah, h. 431.

${ }^{26}$ Syaikh Imam Al-Qurthubi, Tafsir Al-Qurthubi, h. 399. 
dengan tetap tidur bersama istri namun tidak menggaulinya. Tindakan tersebut diharapkan mampu membuat kondisi emosional menjadi netral dan tenang sehingga masalah dapat

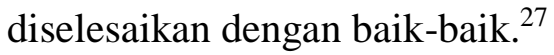

3. Memukul (و اضربو هن)

Ibnu Katsir berpendapat dalam tafsirnya, apabila nasehat tidak bermanfaat dan memisahkan diri dari istri tidak ada hasilnya, maka suami boleh memukul dengan pukulan yang tidak melukai. Seperti sabda Nabi SAW dalam haji wada'nya:

$$
\begin{aligned}
& \text { عن جابر رضي الله عنه قال: قال رسول الله صلّى الله عليه و سلّم: و }
\end{aligned}
$$

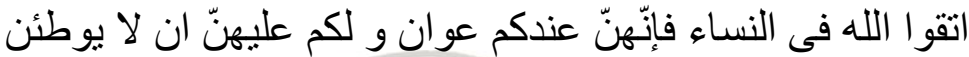

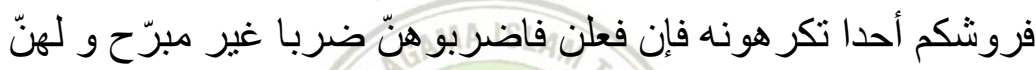

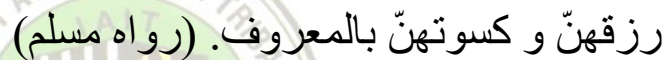

Artinya: "Bertakwalah kepada Allah dalam urusan wanita, karena sesungguhnya mereka di sisi kalian merupakan penolong, dan bagi kalian ada hak atas diri mereka, yaitu mereka tidak boleh mempersilahkan seseorang yang tidak kalian sukai menginjak tempat tidur kalian, dan jika mereka melakukannya, maka pukullah mereka dengan pukulan yang tidak melukakan, dan bagi mereka ada hak mendapat rezeki (nafkah) dan pakaiannya dengan cara ma'ruf."28

M. Quraish Shihab menerjemahkan اضربو هن dengan kata 'pukullah mereka' yang berasal dari kata ضرب y ضرد yang notabene memiliki banyak makna. Sehingga, kata ضرب tidak selalu dapat diartikan dengan menyakiti atau melakukan kekerasan. Dalam al-Quran terdapat kalimat يضربون فى الارض yang artinya orang yang berjalan kaki/musafir. Oleh karena itu,

27 Abdul Halim Hasan, Tafsir al-Ahkam (Jakarta: Kencana, 2006), h. 265.

28 Al-Imam Abul Fida Isma'il Ibnu Katsir Ad-Dimasyqi, Tafsir Ibnu Katsir, Juz V (Jakarta: Sinar Baru Algesindo, 1994), h. 111-112.

Volume 30 Nomor 1 Januari-Juni 2019 
perintah tersebut dapat dipahami berdasarkan penjelasan Rasulullah yakni pemukulan yang tidak menyakitkan. ${ }^{29}$

Imam Syafi'i berpendapat bahwa suami boleh memukul istrinya dalam rangka pendidikan/pengajaran agar tidak berbuat $n u s y \bar{u} z$ lagi. Tapi beliau membatasi yakni dengan pukulan yang tidak berat, tidak menyakiti (ضرب غير مبرّح) dan tidak meninggalkan bekas apalagi berdarah serta menghindari muka (wajah). Akan tetapi, pilihan terbaik adalah tidak memukul sebab hal tersebut menjadi pilihan Rasulullah. ${ }^{30}$ Imam Hanafi, Maliki dan Hanbali juga memiliki pendapat serupa.

Fakhruddin ar-Razi juga mengutip pendapat Imam Syafi'i untuk memperkuat bahwa pemukulan itu dibolehkan tapi menghindarinya jauh lebih baik. Selain itu, ia juga mengutip dari beberapa sahabat Nabi bahwa dalam memukul isteri, suami tidak boleh menggunakan saut, yaitu cambuk atau tongkat. Ia mengungkapkan bahwa Allah menghendaki hukuman yang ringan. jika dengan peringatan tidak tercapai tujuan, seharusnya tidak perlu adanya pemukulan. Menurutnya, seharusnya suami tidak mengarah pada langkah yang sekeras mungkin. ${ }^{31}$

Wahbah al-Zuhaili dan Muhammad Ali ash-Shabuni menyebutkan bagian apa saja yang harus dihindari dalam pemukulan, antara lain: pertama, bagian muka/wajah karena wajah adalah bagian tubuh terhormat. Kedua, perut dan bagianbagian lain yang dapat menyebabkan kematian karena pemukulan ini tidak bermaksud menyakiti apalagi membunuh,

${ }^{29}$ M. Quraish Shihab, Tafsir Al-Mishbah, h. 431.

30 Abu Abdullah Muhammad Bin Idris Asy-Syafi'i, Hukum AlQur'an: Asy-Syafi'i dan Ijtihadnya, terj. Baihaqi Safiuddin (Surabaya: PT Bungkul Indah, 1994), h. 200.

31 Asghar Ali Engineer. Matinya Perempuan: Transformasi alQur'an, Perempuan dan Masyarakat Modern, Judul Asli: The Qur'an, Women and Modern Society, Pentj. Akhmad Affandi, Muh Ihsan, (Yogyakarta: IRCiSoD, 2003), h. 94-95. 
akan tetapi untuk mengubah tabiatnya. Ketiga, memukul hanya pada satu tempat, karena akan memperparah rasa sakit. ${ }^{32}$

At-Thabari dalam kitab tafsirnya mengungkapkan bahwa jika isteri tidak bisa dibujuk dan tidak berhenti melakukan perlawanan dan pemberontakan serta terus menerus menentang suami boleh dikurung dan dipukul. Namun demikian, ia mengingatkan akan kualitas pemukulan tersebut tidak sampai menyakiti (ghair mubarrah) misal dengan menggunakan sikat (miswak) atau lainnya dan tidak melukai (ghair mu'aththarin). ${ }^{33}$ Al-Qurthubi sejalan dengan pendapat tersebut, bahwa pemukulan ini merupakan pukulan pendidikan karena tujuannya merupakan perbaikan hubungan antara suami dan isteri. ${ }^{34}$

Tindakan pemukulan bagi isteri yang nusyzuz ini cukup bias dengan tindak kekerasan dan penindasan terhadap perempuan. Oleh karena itu, Rasyid Ridha menolak anggapan al-Quran hendak melegitimasi bentuk penindasan kaum perempuan melalui term pemukulan ini. Yang perlu digarisbawahi bahwa pemukulan adalah langkah terakhir bila langkah-langkah sebelumnya tidak membawa hasil. Selain itu pemukulan juga tidak dimaksudkan untuk menyakiti isteri. Pemukulan adalah obat pahit (علاج مرّ) dan suami yang shalih tidak akan memukul isterinya meskipun diperbolehkan. Selain itu, ia juga mengutip hadits Rasulullah SAW:

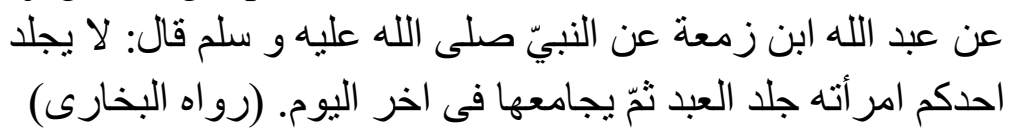

${ }^{32}$ Abdul Aziz Dahlan, Ensiklopedi Hukum Islam, h. 1355,

${ }^{33}$ Abu Ja'far Muhammad Bin Jarir Ath-Thabari, Tafsir Ath-Thabari, VI: 918-919.

${ }^{34}$ Syaikh Imam Al-Qurthubi, Tafsir Al-Qurthubi, h. 401. 
Artinya: "Janganlah salah satu diantara kalian memukul isterinya seperti halnya memukul budak lalu menyetubuhinya pada hari yang lain." (HR. al-Bukhori) ${ }^{35}$

Ada pula sebagian ulama yang berpendapat mengenai kebolehan suami memukul isterinya dalam rangka memberi pelajaran dengan mendasarkan pada Q.S. Shad (38): 44, yang berbunyi:

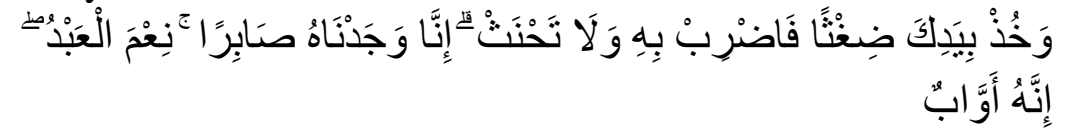

Artinya: "Dan ambillah dengan tanganmu seikat (rumput), Maka pukullah dengan itu dan janganlah kamu melanggar sumpah. Sesungguhnya Kami dapati dia (Ayyub) seorang yang sabar. Dialah sebaik-baik hamba. Sesungguhnya dia amat taat (kepada Tuhan-nya)."

Asbab al-Nuzul ayat di atas merupakan Kisah Nabi Ayyub AS. Beliau pernah bersumpah akan memukul isterinya jika telah pulih dari penyakitnya akibat kelalaian isterinya dalam melayani beliau selama sakit. Akan tetapi beliau merasa kasihan, sehingga karena rasa sayangnya kepada sang isteri beliau tidak mampu memenuhi sumpahnya sehingga turunlah ayat tersebut agar beliau memukulnya dengan seikat rumput agar tidak terasa sakit. Hal ini menunjukkan bahwa dibolehkannya pemukulan terhadap isteri tidak boleh melampaui batas yang layak sebagai pelajaran. $^{36}$

Dalam memahami ayat tentang cara menghadapi istri yang $n u s y \bar{u} z$ ini, para ulama kontemporer memiliki pandangan yang agaknya berbeda dengan ulama-ulama terdahulu. Hal ini terutama terlihat pada pendapat mereka yang berkaitan dengan

35 Ali Yusuf as-Subki, Fiqh Keluarga: Pedoman Berkeluarga dalam Islam, Judul Asli: Nidzam al-Usrah fi al-Islam, Pentj: Nur Khozin (Jakarta: AMZAH, 2010), h. 314.

${ }^{36}$ Muhammad Ali ash-Shabuni, Tafsir Ayat-Ayat Hukum dalam AlQur'an, Judul Asli: Rawai'ul Bayan Tafsir Ayatil Ahkam Minal Qur'an, terj. Saleh Mahfoed (Bandung: PT Al-Ma'arif, 1994), II: 704-705. 
langkah yang terakhir yakni اضربوهن. Hal ini dikarenakan ulama-ulama kontemporer cenderung menyesuaikan pemaknaannya dengan konteks kekinian dimana pemukulan telah dianggap tabu.

Siti Musdah Mulia menyatakan bahwa ayat nusyzuz itu bukan berupa perintah, tetapi merupakan kalimat yang sifatnya khabariyyah, sehingga hanya berlaku pada konteks sosio kultural masyarakat Arab pada saat turunnya ayat tersebut. Ia menambahkan bahwa term اضربوهن ini tidak seharusnya diartikan dengan pemukulan, namun dapat diartikan dengan memberi teladan, mendidik atau bersetubuh. Makna pemukulan ini menurutnya sarat dengan kepentingan satu kelompok tertentu. ${ }^{37}$

Mohammed Talbi, seorang pemikir keagamaan dan sejarawan Tunisia, menawarkan pendekatan historis dalam menafsirkan ayat ini. Ia tidak menolak makna 'pukullah', karena memang pemukulan merupakan salah satu teknik pendisiplinan istri yang justified secara kultural pada masyarakat Arab pada saat Nabi hidup. Ini merupakan fakta historis dan kultural yang tidak dapat diingkari. Namun kebolehan pemukulan disitu merupakan kebolehan yang terpaksa (ibahah karahiyyah). Kebolehan pemukulan ini bukanlah kebolehan yang berlaku untuk semua masa dan tempat. Kebolehan tersebut terikat oleh konteks sejarah saat itu, dimana Allah sebagai Syari' memiliki maksud dan tujuan utama yang lebih jauh yakni menghilangkan sama sekali kebolehan pemukulan ini sejalan dengan hilangnya kondisi-kondisi historis yang mengikatnya, didukung dengan fakta-fakta bahwa Rasulullah tidak pernah memukul istri-

37 Yunahar, Ilyas, Feminisme dalam Kajian Tafsir Al-Qur'an Klasik dan Kontemporer, (Yogyakarta: Pustaka Pelajar, 1997), h. 88. 
istrinya dan beliau pun melarang memukul istri dalam sejumlah hadits. $^{38}$

Amina Wadud menentang pemukulan terhadap istri yang nusyūz. Pemukulan bukan cara terbaik dalam menyelesaikan masalah, tapi justru membuat masalah semakin parah. Pemukulan terhadap isteri yang nusyūz membutuhkan reinterpretasi sebagai cara untuk kembali mengadakan usaha damai dan memperbaiki hubungan antara suami dan isteri. Bahkan menurutnya, langkah yang kedua berupa terapi pisah ranjang merupakan waktu yang tepat untuk memikirkan mengenai keberlanjutan hubungan pernikahan, sehingga apabila selama jangka waktu pisah ranjang suami dan istri merasa pernikahan mereka tidak dapat dilanjutkan lagi, maka lebih baik diakhiri dengan perceraian dan tidak perlu lagi adanya pemukulan sebagai langkah selanjutnya. ${ }^{39}$

Sejumlah mufassir pembaharu seperti Muhammad Abduh, menafsirkannya dengan pukulan kasih sayang yang lembut. Sedangkan sejumlah muslim progresif kontemporer, seperti Edib Yuksel, al-Shaiban dan Nafeh menafsirkan kata dharb ini dengan tinggalkanlah atau ceraikanlah, karena salah satu makna kata dharaba adalah meninggalkan. Dan menurut mereka ini sejalan dengan tindakan Nabi yang tidak pernah menampar atau berbuat kasar kepada istri-istri beliau, sehingga setelah pisah ranjang tidak ada upaya lain kecuali bercerai. ${ }^{40}$

Beberapa pemikir juga berpendapat bahwa al-Quran tidak pernah menganjurkan adanya pemukulan. Salah satunya pendapat Ahmed Ali dari kitab Raghib al-Mufradat fi Gharib alQuran yang dikutip seorang pemikir feminis Ashgar Ali

\footnotetext{
${ }^{38}$ Fariz Pari, dkk. Upaya integrasi hermeneutika dalam kajian qur'an dan hadits (teori dan aplikasi), editor: Syafa'atun Almirzanah dan Sahiron Syamsuddin, Cet. II (Yogyakarta: Lembaga Penelitian UIN Sunan Kalijaga, 2012), h. 279.

${ }^{39}$ Amina Wadud Muhsin, Wanita di dalam, h. 101-102.

${ }^{40}$ Fariz Pari, dkk. Upaya integrasi hermeneutika, h. 277. 
Engineer bahwa term dharaba bermakna metaforis yakni perintah untuk melakukan hubungan seksual.

\section{Kontekstualisasi Konsep Nusyūz}

Bagian dari konsep nusyūz yang banyak mengundang polemik dan perhatian para ulama klasik maupun kontemporer ialah term اضربوهن. Yang menjadi permasalahan ialah ketika term tersebut dimaknai dengan arti pemukulan yang sarat dengan kesan kekerasan. Ayat ini dianggap mendiskreditkan perempuan karena term pemukulan yang dapat dikategorikan dalam tindak kekerasan. Hal ini dikarenakan pemaknaan ayat tersebut yang sering kali melupakan konteks histori turunnya ayat tersebut.

Jika dilihat dari asbab al-nuzul seperti yang telah dipaparkan dalam pembahasan sebelumnya, berdasarkan pendapat S.T Lokhandwala dalam The Position of Women Under Islam yang dikutip oleh Asghar Ali Engineer, Q.S. anNisa' ayat 34 tidak dapat dipisahkan dari sifatnya yang kontekstual, karena suami Habibah binti Zaid bin Abi Zuhair, Sa'ad bin Rabi' merupakan pemuka golongan Anshor. Perintah Rasulullah kepada Habibah untuk mengqishas Sa'ad menuai protes dari kaum laki-laki Madinah. Dominasi kaum laki-laki pada masa itu sangat besar sehingga Rasulullah khawatir akan terjadi kericuhan di tengah-tengah masyarakat Madinah. Kemudian ayat ini turun sebagai solusi yang justru bermaksud mengendalikan kekerasan laki-laki terhadap perempuan dan anjuran untuk menyesuaikan diri dalam masyarakat yang didominasi laki-laki. Ayat ini seolah-olah membenarkan adanya pemukulan terhadap isteri, tetapi Lokhandwala berpendapat sebagaimana dikutip oleh Asghar bahwa ayat ini terbatas pada konteks Madinah saat itu. Ayat ini bukanlah untuk mendorong pemukulan terhadap istri, tetapi mencegahnya dan secara 
bertahap menghapuskannya. Oleh sebab itu, izin pemukulan ditempatkan pada tahap yang terakhir, bukan yang pertama. ${ }^{41}$

Bila dikontekstualisasikan pada masa sekarang, dua langkah pertama untuk menghadapi isteri yang nusyūz yakni menasehati dan pisah ranjang merupakan hal yang masih bisa diterima dan masih dapat dibenarkan. Namun untuk langkah yang ketiga atau terakhir yakni pemukulan, merupakan langkah yang semestinya membutuhkan pemaknaan ulang akibat banyaknya tindak kekerasan terhadap perempuan/isteri yang seringkali dilakukan dengan menggunakan legitimasi nash yang pemaknaannya tidak kontekstual lagi di zamannya. Walaupun tindak pemukulan disebutkan dalam ayat nusyüz, namun pemukulan ini bukan berarti tindak kekerasan, karena tujuan dari pemukulan bukanlah untuk menyakiti, melainkan memberi pelajaran. Bahkan al-Quran memberikan porsi seimbang dalam ayat-ayat lain terdapat perintah untuk mempergauli isteri dengan ma'ruf dan larangan menyakiti isteri atau larangan untuk berbuat kemadharatan terhadap isteri seperti yang terdapat dalam Q.S. al-Baqarah (2): 228-229, dan Q. S. an-Nisa' (4): 19.

Terdapat sebuah hadits yang menyatakan tentang pemukulan terhadap istri:

عن جابر: أن رسول الله صلى الله عليه وسلم قال: اتقوا الله فى النساء

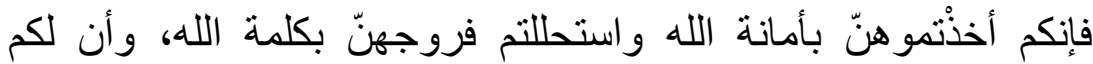

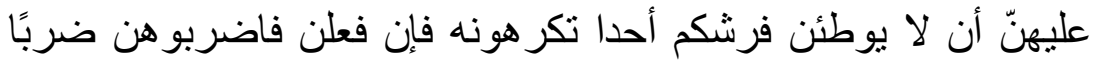

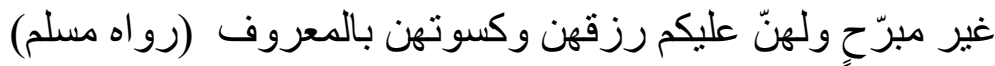
Artinya: "Dari Jabir: Rasulullah SAW bersabda: Takutlah kepada Allah terhadap perempuan karena kamu sekalian telah mengambil mereka sebagi amanah Allah dan dihalalkan bagimu kehormatannya

41 Asghar Ali Engineer, Hak-hak Perempuan dalam Islam, Pentj. Farid Wajidi dan Cici Farkha Assegaf (Yogyakarta: Bentang Budaya, 1994), h. 72-76. 
(menggaulinya) dengan kalimah Allah, dan bagimu agar isteri-isterimu tidak melakukan jima ${ }^{e e}$ dengan laki-laki lain yang tidak kamu sukai di ranjangmu, maka pukullah isteri-isterimu itu dengan pukulan yang tidak menyebabkan luka, dan isteri-isterimu berhak atas rizki dan pakaian yang baik". (H.R. Muslim)

Hadits di atas dapat dipahami bahwa pemukulan diperbolehkan apabila isteri berbuat zina. Selain itu, Muhammad Husein Thabathaba'ie dalam Tafsir al-Mizan memberikan penjelasan terhadap QS. an-Nisa' (4): 19 yang berbunyi:

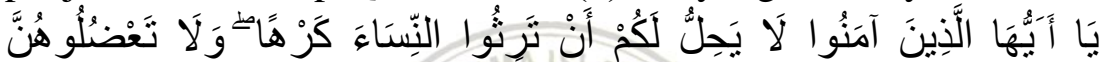

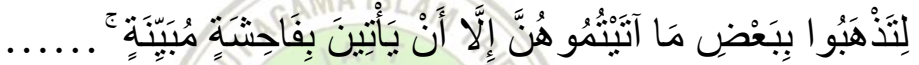

Artinya: "Hai orang-orang yang beriman, tidak halal bagi kamu mempusakai wanita dengan jalan paksa dan janganlah kamu menyusahkan mereka karena hendak mengambil kembali sebagian dari apa yang telah kamu berikan kepadanya, terkecuali bila mereka melakukan pekerjaan keji yang nyata.

Ayat tersebut menjelaskan tentang larangan segala bentuk paksaan dan pengambilan hak istri yang telah diberikan. Namun, terdapat pengecualian yakni fahisyah mubayyinah. Term fahisyah umumnya digunakan dalam penyebutan perbuatan zina, sedangkan mubayyinah dari berarti pembuktian. Sehingga dapat disimpulkan bahwa perbuatan keji tersebut adalah perbuatan zina yang terbukti/dapat dibuktikan. ${ }^{42}$

Hadits dan ayat di atas meniscayakan adanya batasan terhadap tindakan yang dapat dikategorikan nusyzuz. Jika mengacu pada keduanya maka dapat disimpulkan bahwa nusyüz isteri terhadap suami terjadi apabila isteri terbukti berzina. Karena selama ini konsep nusyūz hanya dipahami sebagai

${ }^{42}$ Asghar Ali Engineer, Islam dan Teologi Pembebasan, terj. Agung Prihantoro (Yogyakarta: Pustaka Pelajar, 1999), h. 254-255. 
pembangkangan atau ketidaktaatan isteri terhadap suami, sehingga maknanya menjadi sangat luas. Selain itu, beberapa konsep nusyüz yang telah berkembang yang ditawarkan oleh beberapa ulama klasik juga tidak sesuai lagi dengan keadaan sosio kultural masa kini, misalnya keluarnya isteri dari rumah suaminya yang dianggap sebagai tindakan nusyūz. Tentu hal ini tidak sesuai lagi dengan kondisi saat ini dimana perempuan tidak hanya berperan dalam ranah domestik (ibu rumah tangga), namun juga memiliki peran dalam ruang publik mulai dari kebutuhan pendidikan bahkan tuntutan profesi yang mengharuskan isteri keluar masuk rumah secara bebas.

\section{Aktualisasi Konsep Nusyūz Dalam Kerangka Hukum Positif}

Indonesia termasuk salah satu Negara yang berkomitmen menghapus segala bentuk kekerasan dalam rumah tangga. Hal ini juga dimaksudkan untuk menjunjung tinggi hak asasi manusia, menghapus segala bentuk diskriminasi serta usaha menjunjung tinggi keadilan dan kesetaraan gender. Komitmen tersebut dibuktikan dengan disahkannya UU No. 23 Tahun 2004 tentang Penghapusan Kekerasan Dalam Rumah Tangga (selanjutnya disebut UU PKDRT) pada tanggal 22 September 2004. UU tersebut mengatur tentang segala perbuatan yang termasuk dalam kategori tindak kekerasan dalam rumah tangga, prosedur penanganan perkara, perlindungan terhadap korban KDRT dan sanksi pidana bagi para pelakunya. Pasal 1 UU tersebut menyatakan bahwa tindakan kekerasan dalam rumah tangga adalah:

"Setiap perbuatan terhadap seseorang terutama perempuan, yang berakibat timbulnya kesengsaraan atau penderitaan secara fisik, seksual, psikologis, dan atau menelantarkan rumah tangga, termasuk ancaman untuk perbuatan, pemaksaan, atau perampasan kemerdekaan secara melawan hukum dalam lingkup rumah tangga." 
Sedangkan yang dimaksud dengan lingkup rumah tangga dalam Pasal 2 UU PKDRT adalah meliputi suami, isteri, dan anak; orang-orang yang mempunyai hubungan keluarga dengan (suami, isteri dan anak) karena hubungan darah, perkawinan, persusuan, pengasuhan, dan perwalian, yang menetap dalam rumah tangga; orang yang bekerja membantu rumah tangga dan menetap dalam rumah tangga tersebut.

Secara tegas, kekerasan dalam rumah tangga, diatur dalam Pasal 5 UU PKDRT yang menyatakan bahwa:

"Setiap orang dilarang melakukan kekerasan dalam rumah tangga terhadap orang dalam lingkup rumah tangganya, dengan cara: a) kekerasan fisik; b) kekerasan psikis; c) kekerasan seksual, atau; d) penelantaran rumah tangga".

Adapun bentuk-bentuk kekerasan dalam rumah tangga yang disebutkan dalam UU PKDRT tersebut dibagi menjadi:

1. Kekerasan fisik, yaitu perbuatan yang mengakibatkan rasa sakit, jatuh sakit atau luka berat.

2. Kekerasan psikis, yaitu perbuatan yang mengakibatkan ketakutan, hilangnya rasa percaya diri, hilangnya kemampuan untuk bertindak, rasa percaya diri, dan/atau penderitaan psikis berat pada seseorang.

3. Kekerasan seksual, yaitu pemaksaan hubungan seksual yang dilakukan terhadap orang yang menetap dalam lingkungan rumah tangga tersebut, dan pemaksaan hubungan seksual terhadap salah seorang dalam rumah tangga dengan orang lain untuk tujuan komersial dan/atau tujuan tertentu.

4. Penelantaran rumah tangga, seperti orang yang mengakibatkan ketergantungan ekonomi dengan cara membatasi dan/atau melarang untuk bekerja yang layak di dalam atau di luar rumah sehingga korban berada di bawah kendali orang tersebut. ${ }^{43}$

${ }^{43}$ Pasal 5-9 UU No. 23 Tahun 2004 tentang PKDRT. 
Jika dilihat dari bentuk-bentuk KDRT di atas, maka pemukulan merupakan tindakan kekerasan dalam rumah tangga yang dapat dikategorikan dalam kekerasan fisik karena dapat mengakibatkan rasa sakit hingga luka berat. Sehingga hal itu dapat disebut sebagai tindak pidana yang berkonsekuensi terhadap adanya sanksi pidana bagi pelakunya. Maka konsep nusyuz pada term pemukulan tidak bisa semata-mata dipahami sebagai bentuk memberikan rasa sakit kepada istri, karena hal tersebut merupakan tindakan pelanggaran menurut UU PKDRT. Bahkan dapat dikatakan bahwa pemukulan terhadap isteri yang $n u s y \bar{u} z$ sebagai bentuk pelajaran dapat dikatakan sudah tidak relevan lagi untuk dilakukan di Indonesia. Dikarenakan bentuk kekerasan yang diundang-undangkan dalam UU PKDRT telah dimaknai secara lebih luas meliputi kekerasan fisik, psikis maupun seksual. Sehingga, tidak ada sedikitpun bentuk tekanan terhadap perempuan yang dapat ditolerir berdasarkan UU PKDRT ini. ${ }^{44}$

Selain itu, ada beberapa pendapat ulama klasik terkait konsep nusyūz yang agaknya bersifat kontradiktif dengan ketentuan dalam UU PKDRT, seperti menolak ajakan suami untuk menggauli (jima') yang dianggap sebagai tindakan nusyūz. Hal ini dapat membuka peluang terjadinya kekerasan seksual apabila terdapat unsur pemaksaan dalam melakukannya sebagaimana tercantum dalam UU PKDRT misalkan istri dalam keadaan kelelahan atau pun sakit. Sehingga dapat dikatakan bahwa konsep yang semacam itu tidak dapat lagi diterapkan dalam konteks saat ini karena terdapat unsur diskriminasi dan kesewenang-wenangan terhadap perempuan bahkan kekerasan yang tidak dapat dibenarkan oleh hukum positif di Indonesia.

44 Rahma Pramudya Nawang Sari, "Nusyūz-Maritale Rape (KDRT) Perspektif Hukum Perkawinan Islam," Jurnal Al-Ahwal, Vol. 3 No. 1, 2012 M/ $1433 \mathrm{H}$. 


\section{Penutup}

Berdasarkan pemaparan di atas, dapat di pahami bahwa konsep nusyüz perlu diinterpretasikan ulang disesuaikan dengan kondisi sosio kultural dan pranata hukum yang ada. Term pemukulan yang ada dalam konsep nusyūz tidak dapat dipahami sebagai bentuk kekerasan dalam rumah tangga yang notabene termasuk dalam kategori tindak pidana dalam hukum positif kita. Hal tersebut harus dimaknai lebih humanis yakni sebagai bentuk pendidikan yang diberikan oleh suami kepada istri. Karena pada hakikatnya hukum Islam melalui konsepkonsepnya, dalam hal ini konsep nusyüz, tidak dapat terlepas dari tujuan pensyariatan (maqashid al-syari'ah) yang menjunjung tinggi hak asasi manusia dan meghapuskan segala tindakan kekerasan yang bersifat diskriminatif. 


\section{DAFTAR PUSTAKA}

Dahlan, Abdul Aziz. Ensiklopedi Hukum Islam, Vol. 4, Cet. I. Jakarta: Ichtiar Baru Van Hoeve, 1996.

Dimasyqi, Al-Imam Abul Fida Isma'il Ibnu Katsir Ad-. Terjemahan Tafsir Ibnu Katsir, Juz V. Jakarta: Sinar Baru Algesindo, 1994.

Engineer, Asghar Ali, Hak-hak Perempuan dalam Islam, terj. Farid Wajidi dan Cici Farkha Assegaf. Yogyakarta: Bentang Budaya, 1994.

- Islam dan Teologi Pembebasan, terj. Agung Prihantoro. Yogyakarta: Pustaka Pelajar, 1999.

- Matinya Perempuan: Transformasi al-Quran, Perempuan dan Masyarakat Modern, Judul Asli: The Qur'an, Women and Modern Society, terj. Akhmad Affandi, Muh Ihsan. Yogyakarta: IRCiSoD, 2003.

Ghazali, Al-. Menyingkap Hakikat Perkawinan: Adab, Tata Cara dan Hikmahnya, cet. ke-10, terj. Muhammad alBaqir. Bandung : Karisma, 1999.

Hamka. Tafsir al-Azhar, Juz V. Jakarta: Pustaka Panjimas, 1983. Hasan, Abdul Halim. Tafsir Al-Ahkam. Jakarta: Kencana, 2006.

Jauziyah, Ibnu Qayyim al-. I'lam al-Muwaqqiin an Rab alAlamin. Beirut: Dar al-Fikr, t. th.

Muhsin, Amina Wadud. Wanita di dalam Al-Quran, Judul Asli: Al-Quran and Woman, editor: Ammar Haryono. Bandung: Pustaka, 1994.

Mukhtar, Kamal. Asas-Asas Hukum Islam tentang Perkawinan, Cet. III. Jakarta: Bulan Bintang, 1993.

Nasution, Khoiruddin. Hukum Perkawinan 1, ed. revisi. Yogyakarta: ACAdeMIA + TAZZAFA, 2005.

Pari, Fariz, dkk. Upaya Integrasi Hermeneutika dalam Kajian Qur'an dan Hadits (Teori dan Aplikasi), editor: Syafa'atun Almirzanah dan Sahiron Syamsuddin, Cet. 
Kontekstuliasasi Nusyuz... Oleh: Mughniatul Ilma

II. Yogyakarta: Lembaga Penelitian UIN Sunan Kalijaga, 2012.

Qurthubi, Syaikh Imam Al-. Tafsir Al-Qurthubi, terj. Ahmad Rijali Kadir. Jakarta: Pustaka Azzam, 2008.

Rohman, Dudung Abdul. Mengembangkan Etika Berumah Tangga Menjaga Moralitas Bangsa Menurut Pandangan Al-Quran. Bandung: Nuansa Aulia, 2006.

Sabiq, Sayyid. Fiqh al-Sunnah. Madinah: al-Fath Li I'lami al'Araby, 1990.

Sadlani, Shaleh bin Ghanim As-. Nusyūz , Konflik Suami Isteri dan Penyelesaiannya, terj. Muhammad Abdul Ghafar. Jakarta: Pustaka al-Kautsar, 1993.

Sari, Rahma Pramudya Nawang. "Nusyūz-Maritale Rape (KDRT) Perspektif Hukum Perkawinan Islam," Jurnal Al-Ahwal, Vol. 3 No. 1, 2012 M/1433 H.

Shabuni, Muhammad Ali Ash-. Rawai'ul Bayan: Tafsir AyatAyat Hukum, terj. Moh. Zuhri dan M. Qodirun Nur. Semarang: Asy-Syifa, 1993.

. Tafsir Ayat-Ayat Hukum dalam Al-Quran, Judul Asli: Rawai'ul Bayan Tafsir Ayatil Ahkam Minal Qur'an, Pentj. Saleh Mahfoed. Bandung: PT Al-Ma'arif, 1994.

Shihab, M. Quraish. Tafsir Al-Mishbah: Pesan, Kesan dan Keserasian Al-Quran, Vol. 2. Jakarta: Lentera Hati, 2006.

Subki, Ali Yusuf As-. Fiqh Keluarga: Pedoman Berkeluarga dalam Islam, Judul Asli: Nidzam al-Usrah fi al-Islam, terj: Nur Khozin. Jakarta: AMZAH, 2010.

Syafi'i, Abu Abdullah Muhammad Bin Idris Asy-. Hukum AlQuran: Asy-Syafi'i dan Ijtihadnya, terj. Baihaqi Safiuddin. Surabaya: PT Bungkul Indah, 1994.

Thabari, Abu Ja'far Muhammad Bin Jarir Ath-. Tafsir AthThabari, terj. Akhmad Affandi. Jakarta: Pustaka Azzam, 2008. 
Kontekstualisasi Nusyuz... Oleh: Mughniatul Ilma

Yunahar, Ilyas. Feminisme dalam Kajian Tafsir Al-Quran Klasik dan Kontemporer. Yogyakarta: Pustaka Pelajar, 1997. 